\title{
From the Experience in Enhancing Individual Responsibility for the Protection of Own Physical Health through Healthy Nutrition
}

\author{
Afet Suleymanova* \\ Ministry of Education of the Republic of Azerbaijan, Azerbaijan \\ Submission: January 16, 2018; Published: February 15, 2018 \\ *Corresponding author: Afet Suleymanova, Ministry of Education of the Republic of Azerbaijan, AZ1008, Baku city, Khataiavenue, 49, \\ Email: a.suleymanova@edu.gov.az; afetstf@mail.ru
}

\section{Opinion}

Education is the upbringing of values. Physical health is among the most important values. If the person is not healthy, the contribution he / she can make to own and the community life is reduced to the minimum. The century we live, along with many factors such as hypo dynamics, excessive use of technical means, unhealthy nutrition adversely affects human health. It becomes important to learn from the earliest age, that health is a value, and everybody is responsible to protect and increase own health.

This is a need which has to be reflected in content, learning strategies, recourses of education, as well as in the infrastructure, design and supply of general and pre-school educational institutions. For this purpose, the Ministry of Education and The Ministry of Health of the Republic of Azerbaijan carried out a series of joint activities.

Healthy lifestyle and healthy nutrition issues are reflected in the State Standards of General Education of the Republic of Azerbaijan and curricula of various disciplines. In the curriculum of "Knowledge of Life", "Physical Education" and "Biology" this issues were highlighted in the most vivid manner.

"Knowledge of Life" is an integrative discipline that helps the individual to formulate and improve the knowledge, skills and values needed to perceive and realize himself as a whole, with his biological, psychological, social and spiritual aspects. Healthy lifestyle issues are of particular importance in the content of the subject. The document states: "Students are formed as individuals who follow sanitary, hygienic rules, consciously benefit from all the benefits of life, abstain from all harmful habits (smoking, alcohol and drugs), and, when necessary, help themselves and their mates, and the ability to make the right decision when choosing foods*.
Scientific research institutes, research centers under both ministries Education and Health were expanded researches, provided monitoring, conducted social surveys on food and healthy nutrition issues together with NGOs.

In the frame of the project "Healthy education-healthy nation" implemented by the Ministry of Education at 37 elementary schools from 2014 onwards, there were conducted extensive work on enlightenment of parents, students as well as teachers, school administrators and school service personal on healthy nutrition issues such as:

I. Schoolchildren's food ration and the basic rules of nutrition

II. Harmful food products, malnutrition and their complications

III. Nutrition mode, complications of feeding without regime

IV. Food label and hygiene rules

In schools was held the "Month of Healthy Nutrition". During the month, students made informational speeches on the topic "Healthy food" to their comrades in classrooms, school corridors in break time. At the end of the event, a public information campaign was conducted. Students wearing clothes similar to food products (fruits, vegetables, dairy products, meat products and so on) informed other students, parents, teachers and other guests about the benefits of these products. Beside of them, children created and presented informative posters on genetically modified product and fast foods' damages. Together with the Public Health and Reforms Center of the Ministry of Health of the Republic of Azerbaijan was conducted assessment of healthy nutrition among the canteen at six schools in capital city Baku, and nineteen schools of Ganja city, and districts such as Gazakh, Gakh, Quba,

*State Standards of General Education of the Republic of Azerbaijan, "Knowledge of Life" curriculum (I-IV grades), pp. 9 
Lankaran and Saatli. Also, there were conducted monitoring to determine the most commonly used foods for students. "Health Forums" has been held in two general schools of capital city of Baku and Ganja. The forum sessions were followed by students on the following topics:

I. Features of healthy nutrition

II. Reading labels on products

III. Harmful foods

IV. Vitamins and minerals which are important for teenage organisms

V. Physical activity and youth (Figure 1)

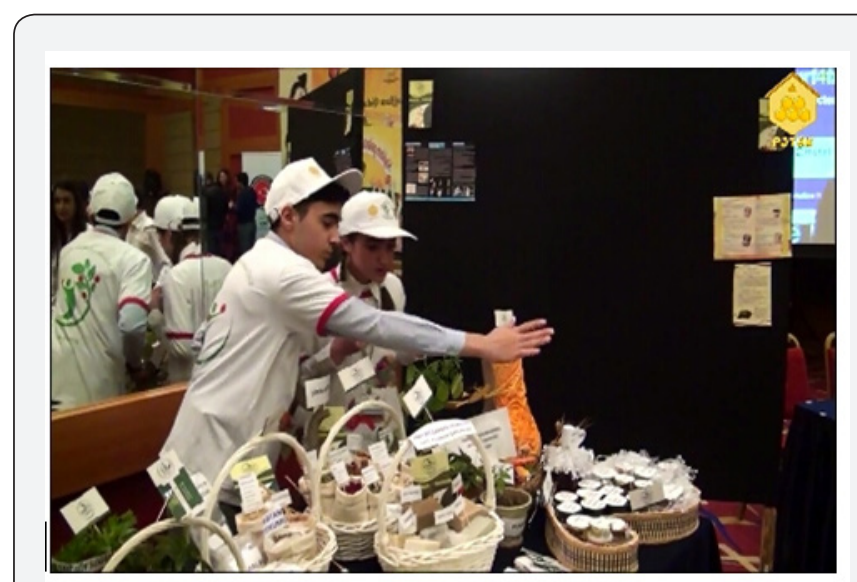

Figure 1:

Extensive opportunities are being created for the implementation of NGO projects on healthy nutrition. In February 2014, Public Union "Petek" started a project called "Healthy Food - Healthy Generation" in Baku schools. From 2016, the second phase of the project has been launched called "Healthy Lifestyle". Also, there were established the clubs in schools: "Let's be Healthy». In this clubs once in a month are held meetings on a variety of topics, including health nutrition issues .In the frame of this project were provided competitions on various nominations involving 1,080 pupils from 18 general schools of Fizuli, Aghdam, Kalbajar and Baku. The following number of pupils has been announced as winners on various nominations in different cities and regions of the Republic of Azerbaijan:

I. The better composition - 286 pupils

II. The better electronic presentation - 65 pupils
III. The better feature presentations - 8 presentations (Figure 2-3)

Ecological problems that occur in the surrounding environment, unhealthy foods and nutrition, the hypo dynamic life style shaped by the development of science and technology and the psychological pressure have a negative influence on people's health, especially new generation. For being able to be protected, from these and other negative influences, learning the ways of protection and development of own health is one of the main challenges facing education. In order to take steps for the joint efforts in this direction, is required new researches, new methods on sustainable co-operation of educators and healthcare workers. Every new step taken in this direction is worthwhile.
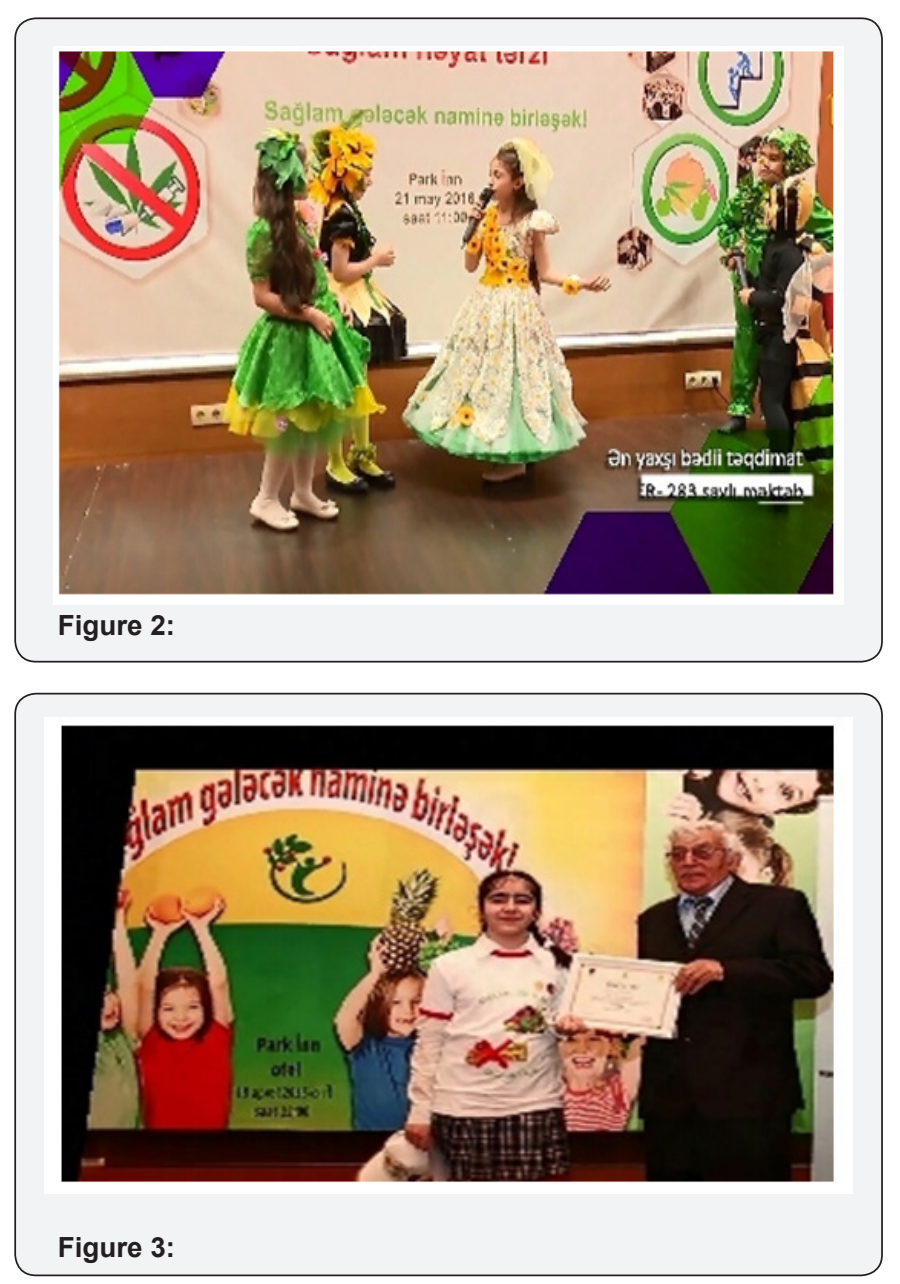

*State Standards of General Education of the Republic of Azerbaijan, "Knowledge of Life" curriculum (I-IV grades), pp. 9 
This work is licensed under Creative Commons Attribution 4.0 License

DOI: $10.19080 /$ NFSIJ.2018.05.555659

\section{Your next submission with Juniper Publishers} will reach you the below assets

- Quality Editorial service

- Swift Peer Review

- Reprints availability

- E-prints Service

- Manuscript Podcast for convenient understanding

- Global attainment for your research

- Manuscript accessibility in different formats ( Pdf, E-pub, Full Text, Audio)

- Unceasing customer service

Track the below URL for one-step submission https://juniperpublishers.com/online-submission.php 